\title{
How Milton Friedman Exploited White Supremacy to Privatize Education
}

\author{
Nancy MacLean*
}

\author{
Working Paper No. 161
}

\section{September $1^{\text {st }}, 2021$}

\begin{abstract}
This paper traces the origins of today's campaigns for school vouchers and other modes of public funding for private education to efforts by Milton Friedman beginning in 1955. It reveals that the endgame of the "school choice" enterprise for libertarians was not thenand is not now--to enhance education for all children; it was a strategy, ultimately, to offload the full cost of schooling onto parents as part of a larger quest to privatize public services and resources. Based on extensive original archival research, this paper shows how Friedman's case for vouchers to promote "educational freedom" buttressed the case of Southern advocates of the policy of massive resistance to Brown v. Board of Education. His approach-supported by many other Mont Pelerin Society members and leading libertarians of the day --taught white supremacists a more sophisticated, and for more than a decade, court-proof way to preserve Jim Crow. All they had to do was cease overt focus on race and instead deploy a neoliberal language of personal liberty, government failure and the need for market competition in the provision of public education.
\end{abstract}

\section{https://doi.org/10.36687/inetwp161}

JEL codes: B25, I20, I24, I28.

Keywords: School choice, Milton Friedman, public vs. private education, Jim Crow

\footnotetext{
* Professor of History and Public Policy, Duke University.
} 
As a new school year starts during a protracted public health crisis, students, teachers and school staff face grave risk of infection from the Delta variant of the COVID-19 virus. Yet they also face a more perennial peril: the decades-long push to privatize - and undermine--public education under the slogan of "school choice." The year 2021 proved a landmark for the cause, as Republican control of a majority of state legislatures combined with learning disruptions from the pandemic set the stage for multiple victories. Seven U.S. states have created new "school choice" programs and eleven others have expanded current programs, with laws that authorize taxpayer-funded vouchers for private schooling, provide tax credits, and authorize educational savings accounts to invite parents to abandon public schools. ${ }^{1}$

A well-funded, laser-focused and integrated long game helped achieve these legislative triumphs. Indeed, it is difficult to find an institution on the American right that has not advocated "school choice." Think tanks such as the Cato Institute and the Heritage Foundation, along with affiliates of the State Policy Network, make the case for it. Engines of legal and judicial change such as the Federalist Society and the Institute for Justice workshop the constitutional issues and litigate for it. The American Legislative Exchange Council (ALEC) produces templates of "model laws" for its overwhelmingly Republican members to introduce it in state legislatures. Fox News broadcasts the talking points. Organizing efforts including Americans for Prosperity drive calls and letters to elected officials. Deep-pocketed donors underwrite the work. The campaigners employ a common language of personal liberty and anti-government, pro-market catch phrases. They tout the benefits of parents gaining the "freedom to choose" to send their children to private schools. And they claim that breaking up the "government monopoly" will promote "competition" that will improve the overall quality of education. ${ }^{2}$

\footnotetext{
1 Alan Greenblatt, "School Choice Advances in the States: Advocates Describe 'Breakthrough Year," Education Next, Summer 2021: https://www.educationnext.org/school-choice-advances-in-statesadvocates-describe-breakthrough-year/?utm_source=pocket_mylist. For ongoing coverage of such efforts, see the Education pages maintained by In the Public Interest and Diane Ravitch's Blog: https://www.inthepublicinterest.org/category/sectors/education/ and https://dianeravitch.net/ . ${ }^{2}$ For a sampling, simply search the name of the organization and "vouchers" or "school choice." For critique of ALEC in particular, see the Center for Media and Democracy's ALEC Exposed research, including the page entitled "Privatizing Public Education, Higher Ed Policy, and Teachers": https://www.alecexposed.org/wiki/Privatizing Public Education, Higher Ed Policy, and Teachers
} 
"School choice" sounds like it offers options. But as I will show, the whole concept, as first implemented in the U.S. South in the mid-1950s, aimed to deny the choice of equal, integrated education to Black families. Further, Milton Friedman, soon to become the best-known neoliberal economist in the world, abetted the push for private schooling that southern states used to evade the reach of Brown v. Board of Education, the Supreme Court's unanimous 1954 ruling that the segregation of public education violated the constitutional right of Black children to equal protection of the laws. So, too, did other libertarians of the day, among them leading pioneers of the cause that today avidly pushes private schooling. ${ }^{3}$

Perhaps most tellingly, though, the ultimate purpose was not really to benefit parents and children, even the white ones who patronized the new segregation academies. For Friedman and the libertarians, school choice was and is a strategy to ultimately offload the burden of paying for education onto parents, thus harming the educational prospects of most youth. As we will see, Friedman himself hoped it would discourage low-income parents from having children in a form of economic social engineering reminiscent of eugenics. He predicted that once they had to pay the entire cost of schooling from their own earnings, they would make different reproductive decisions. ${ }^{4}$

Friedman was in his 40s and on the faculty at the University of Chicago when he launched this campaign. He had been among the founders of the Mont Pelerin Society, the transnational invitation-only body launched in 1947 to convene the neoliberal cause,

\footnotetext{
${ }^{3}$ Some readers will know that I made a related argument in Democracy in Chains: The Deep History of the Radical Right's Stealth Plan for America (New York: Viking Press, 2017). That book focused on James McGill Buchanan and Charles Koch. Here I circle back to the earlier research that led me to them, which concerned Milton Friedman's venture South to win the future. Since I did this research, another author and longtime civil rights advocate, Steve Suitts, has published a complementary case in his article, "Segregationists, Libertarians, and the Modern School Choice Movement," Southern Spaces, June 4, 2019, and book, Overturning Brown: The Segregationist Legacy of the Modern School Choice Movement (New South Books, 2020). Suitts's coverage of the current situation is excellent, but his origins story is flawed. In emphasizing Alabama, the site of his life's work, he misses the leading role of shrewd Virginia actors, as well as the wider history conveyed in this article.

${ }^{4}$ As Robert W. Poole of the Reason Foundation, once put it, the libertarian dream is a "full liability society." That is: you make the choice to have children? Fine, but do not expect other taxpayers to help you in any way. It was your choice, and now you bear full liability for all its costs. Robert W. Poole, Jr, "Reason and Ecology," in Outside, Looking In: Critiques of American Policies and Institutions, Left and Right (New York: Harper \& Row, 1972), 253.
} 
and at that point was less well-known than elders such as Friedrich Hayek, Frank Knight, and Ludwig von Mises. But that would change when his wife, Rose Director Friedman, also an economist, took her husband's notes from a 1956 lecture series and turned them into Capitalism and Freedom.

Eventually translated into eighteen languages, the book made him famous the world over. The splash led to a politically engaged career that included advising Barry Goldwater during his 1964 run for the presidency and the administrations of President Ronald Reagan and the British Prime Minister Margaret Thatcher, among others. Friedman's scholarship focused on monetary theory and history in a quest to refute the Keynesian economics adopted by western governments since the Great Depression and World War II; it was awarded the Nobel Memorial Prize in Economic Sciences in $1976 .{ }^{5}$

But Friedman's passion for over half century, from 1955 until his death in 2006, was promoting school choice. He championed what he called educational freedom in print and speech, engaged in the trenches of policy fights for it, and created a foundation to further it, originally called the Milton and Rose D. Friedman Foundation, and since renamed EdChoice. ${ }^{6}$

This is the story of how it all started--and how it aided white resistance to the Black freedom movement in the South. With Friedman in the lead, numerous libertarian theorists and organizations saw in the backlash to the desegregation decree an opportunity they might leverage to advance their goal of privatizing government services and resources. Whatever their personal beliefs about race and racism, they helped Jim Crow survive by providing ostensibly race-neutral arguments for tax subsidies to the private schools sought by white supremacists. Indeed, to achieve court-proof vouchers, leading defenders of segregation learned that the best strategy was to abandon overtly

\footnotetext{
${ }^{5}$ The Friedmans told their story in Milton Friedman and Rose D. Friedman, Two Lucky People: Memoirs (Chicago: University of Chicago Press, 1998). For how the lectures became a book, treated as soleauthored in its original incarnation, see Milton Friedman with the assistance of Rose D. Friedman, Capitalism and Freedom, $40^{\text {th }}$ Anniversary Edition (orig. pub. 1962; Chicago: University of Chicago Press, 2002), 1982 Preface, xi.

${ }^{6}$ Friedman's records contain abundant documentation of his ongoing efforts to promote school choice. See Milton Friedman Papers, Hoover Institution Archives, Stanford University, Palo Alto, CA.
} 
racist rationales and embrace both an anti-government stance and a positive rubric of liberty, competition, and market choice.

The pattern took shape most clearly in Virginia, the driver of a regionwide strategy of "massive resistance" to the mandate to desegregate public schooling. Goaded by the U.S. Senator Harry F. Byrd and the Richmond journalist James J. (Jack) Kilpatrick, the state passed a set of mutually reinforcing laws to prevent integration in 1956. One essential element was tax-funded tuition grants (what today we would call vouchers) to enable white parents to send their children to private schools, which were beyond the reach of the Brown ruling. ${ }^{7}$ Virginia and other states maintained the vouchers until 1968. That was when the U.S. Supreme Court, in a Virginia-based case, outlawed them as intentionally discriminatory. ${ }^{8}$ Yet Milton Friedman held up that purposefully discriminatory Virginia plan as a model for schooling everywhere in Capitalism and Freedom. "Whether the school is integrated or not," he wrote, should have no bearing on eligibility for the vouchers. ${ }^{9}$ Behind those words was a telling history.

Milton Friedman published his first manifesto for school vouchers in 1955, the year after the Supreme Court's ruling in Brown v. Board of Education. The article, titled innocuously, "The Role of Government in Education," pronounced the mid-1950s an opportune time "to re-examine the existing activities of government." 10 It was the right moment, he said, for "a fresh assessment" to identify those activities "that are not

\footnotetext{
7 For an excellent and easily accessible overview, see James H. Hershman, "The Origins of Massive Resistance," Encyclopedia Virginia: https://encyclopediavirginia.org/entries/massive-resistance/ ${ }^{8}$ The case was Green v. County School Board of New Kent County. The most recent and comprehensive history of Black Virginians' ordeal is Brian J. Daugherity, Keep on Keeping On: The NAACP and the Implementation of Brown v. Board of Education in Virginia (Charlottesville: University of Virginia Press, 2016).

${ }^{9}$ Milton Friedman with the assistance of Rose D. Friedman, Capitalism and Freedom, 118.

${ }^{10}$ Economics and the Public Interest, ed. Robert A. Solo (New Brunswick, N.J.: Rutgers University Press, 1955), vii. It is no exaggeration to call it a manifesto; Friedman understood it as such. He appealed to what is now the American Enterprise Institute to issue it in "a more readily available form" than where it was "more or less buried." He suggested "pamphlet form." Friedman to Glen Campbell, April 14, 1958, box 22, Friedman Papers.
} 
justified." The provision of schooling was his case in point: why, Friedman asked, should Americans abide a government "monopoly" in schooling? ${ }^{11}$

Friedman allowed that "a stable and democratic society" had an interest in at least "a minimum level of literacy" and "general education for citizenship," which made it reasonable to insist on rudimentary schooling for all. But why should government pay for that schooling? Why shouldn't it just "require the parents to meet the costs directly"? After all, he said, that would discourage childbearing among "the lower socio-economic groups" who could not afford the cost. "Fantastic as it may at first appear," charging parents for education could "noticeably affect the size of families," by leading those of lesser means to have fewer children. Alas, he rued, charging parents for schooling currently seemed "hardly feasible." 12

Still, probed Friedman, even if citizens agreed that government should both require and fund education, why should it operate the schools? His thesis was that it should not. The long tradition of public education in America, going back to Horace Mann in antebellum New England, had been a mistake. Friedman offered a radical vision in its stead: government should give all parents "vouchers" with which to purchase "educational services" from approved vendors, whether non-profit or profit-making. A market-based system would expand "the range of choice available to parents" because with subsidies available, "a wide variety of schools will spring up to meet demand."13 The prime example Friedman adduced for how such a system might work was the GI Bill, passed a decade before to assist returning veterans in obtaining higher education. The government did not run schools for returning soldiers; it merely provided tuition subsidies that recipients could apply at accredited institutions. The vital thing for Friedman was to end the state's "monopoly" over the "administration" of education, for it was not "justifiable... in a predominantly free enterprise society." 14

\footnotetext{
${ }^{11}$ Milton Friedman, "The Role of Government in Education," in Economics and the Public Interest, $123-$ 44. Robert A. Solo should not be confused with Robert M. Solow, the Nobel laureate.

${ }^{12}$ Friedman, "The Role of Government in Education," 123-26.

${ }^{13}$ Friedman, "Role of Government,"123-129.

${ }^{14}$ Friedman, "Role of Government," 127-28.
} 
Friedman crafted his argument in a context in which segregationist threats to prevent public schools from being integrated were being widely reported. In 1951, the very day Black children in Prince Edward County, Virginia filed a lawsuit to end Jim Crow schooling, the state's leading daily newspaper editorialized that it might soon be time to "abandon tax-supported public education altogether." 15 The idea of forsaking public education spread as the litigation that ended in the Brown ruling wended its way through the courts. The following year, South Carolina's white supremacist "elder statesman" and sitting Governor James F. Byrnes won white voters' backing for an amendment to the state's constitution to enable closure of public schools if the courts outlawed segregation. ${ }^{16}$ In 1953, Georgia's Governor Herman Talmadge put forth a constitutional amendment to provide for the conversion of the state's public schools to private schools and the provision of tax-funded tuition grants for those who patronized them. "We can maintain [racially] separate schools regardless of the U.S. Supreme Court," the Governor announced, "by reverting to a private system, subsidizing the child" rather than the school. Talmadge went on to warn that before his state obeyed a desegregation order "blood will flow in rivers."17

In short, by the time Friedman set to work on his article national newspapers were abuzz with the clamor in Dixie for private schools to save segregation and for state subsidies to make mass white flight viable. A regular reader couldn't miss it. ${ }^{18}$

Robert A. Solo, the economist editing the volume in which Friedman's essay was to appear, was a case in point. He saw instantly how Friedman's argument would aid the massive resisters. Worried, Solo wrote to Friedman to ask whether he had considered how his case could abet the efforts of white officials in the South who were making such

\footnotetext{
${ }^{15}$ Richmond News Leader, 7 May 1951.

${ }^{16}$ Jason Morgan Ward, Defending White Democracy: The Making of a Segregationist Movement and the Remaking of Racial Politics, 1936-1965 (Chapel Hill: University of North Carolina Press; 2011), 137-139; Hershman, Jr., "A Rumbling in the Museum: The Opponents of Virginia's Massive Resistance" (Ph.D. Dissertation, University of Virginia, 1978), 28-29.

${ }^{17}$ Kevin M. Kruse, White Flight: Atlanta and the Making of Modern Conservatism (Princeton: Princeton University Press, 2005), esp. 132-33.

${ }^{18}$ Numan V. Bartley, The Rise of Massive Resistance: Race and Politics during the 1950s (orig. pub. 1969; reprint Baton Rouge: Louisiana State University Press, 1997), 45, 54-56.
} 
threats, urging him to see the danger. ${ }^{19}$ After all, in the U.S. Senate, Virginia's longserving U.S. Senator Harry F. Byrd called Brown "the most serious blow that has yet been struck against the rights of the states." ${ }^{20}$ By July of 1954, national news outlets were reporting that Byrd's followers were calling for the shutdown of the state school system and the use of tax dollars to fund new private segregated schools for white children. ${ }^{21}$

In reply to Solo's concern, Friedman added a long footnote that staked out his position on the expanding Black freedom struggle. He acknowledged that "essentially this proposal - public funding but private operation of education - has recently been suggested in several southern states as a means of evading the Supreme Court ruling against segregation." He also saw that his plan could lead to "the exacerbating of class distinctions," as contemporary critics of those state governments predicted. But Friedman made his case anyway, he said, because "principles can be tested best by extreme cases." "I deplore segregation and prejudice," he assured, and "oppose forced segregation." But, he insisted, government should not be allowed "to try to force individuals to act in accordance with my_or anyone else's_-views." This principle led him to "equally to oppose forced nonsegregation.” In Friedman's view “forced nonsegregation," which was what Black litigants sought and the Supreme Court required in keeping with the constitutional principle of equal protection of the law, was equivalent to forced segregation by law - because both enlisted state power. State laws mandating segregation might be deplorable, but Brown was also unacceptably coercive, in his view, as would be any civil rights enforcement by the government. ${ }^{22}$

Friedman had a simple solution. "Privately conducted schools can resolve the dilemma" between one compulsory system and the other. "Under such a system, there can develop

\footnotetext{
${ }^{19}$ Robert Solo to Milton Friedman, Oct. 12, 1954, box 33, Friedman Papers.

${ }^{20}$ Gene Roberts and Hank Klibanoff, The Race Beat: The Press, the Civil Rights Struggle, and the Awakening of a Nation (New York: Random House, 2006), 61-62; Robert Solo to Milton Friedman, Oct. 12, 1954, box 33, Friedman Papers.

${ }^{21}$ Roberts and Klibanoff. The Race Beat, 67; James H. Hershman, Jr. "The Emergence of the "Virginia Plan' of Private Segregation Academies," July 30, 2012, unpublished paper in author's possession. ${ }^{22}$ Friedman, "Role of Government," 131, n. 2. The original article with its note 2 was long posted on the website of the Milton and Rose Friedman Foundation, which was devoted to school privatization. It has since been renamed EdChoice; the new site carries the 1955 article and its note, too: https:/www.edchoice.org/who-we-are/our-founders/the-friedmans-on-school-choice/article/the-role-ofgovernment-in-education/
} 
exclusively white schools, exclusively colored schools, and mixed schools. Parents can choose which to send their children to." Why, he asked, should schooling be any different from, say, summer camps, some of which were "wholly Jewish, some wholly nonJewish, and others mixed"? Those who opposed racism and hoped to promote "mixed schools" should not ask government to step in where it was not "appropriate." They should "try to persuade others of their views" so there might be a voluntary "gradual transition." ${ }^{23}$ Gradual transition? Black Americans had been trying to persuade white officials that segregation was wrong for generations and they had been organizing and litigating toward equal schools for decades. But because they were disenfranchised, "others" had been able ignore or out-maneuver them-until Brown. ${ }^{24}$

Systemic racism did not yet carry that name, but it is precisely what Friedman refused to acknowledge. His conversion to what he called the "new faith" of neoliberalism, which posited a fiction of equal individuals, abstracted from context, who freely chose in fair markets, blinded Friedman to what was so evident to Robert Solo. ${ }^{25}$ In their correspondence before publication, Solo pointed out that Friedman was ignoring the actual social and political context of the court's ruling. History had shown that "this context cannot be changed by individual action," particularly in a region that practiced voter suppression. It was "alterable only by collective action." Solo insisted that segregation was far more than, as Friedman purported, "a mere matter of free choice," of

\footnotetext{
${ }^{23}$ Friedman, "Role of Government," 131, n. 2.

${ }^{24}$ See J. Douglass Smith, Managing White Supremacy: Race, Politics and Citizenship in Jim Crow Virginia (Chapel Hill: University of North Carolina Press, 2002); Daugherity, Keep on Keeping On.

25 "We have a new faith to offer," he said in his first piece on the subject. Milton Friedman, "The Prospects for Neoliberalism," Farmand, Feb. 17, 1951. Before committing to this dogma, the young Milton Friedman could see state-sponsored racial injustice just as Solo and so many contemporaries did by the 1950s. Back in his 1937 when he had too "strong New Deal leanings" for his brother-in-law to be, the University of Chicago professor Aaron Director, founder of the field of law and economics, this was description of Bermuda, "The dominant white group uses every means to suppress the negroes." The white elite required property qualifications for voting, for example, to ensure that only about a tenth of the population could vote--with the result that Blacks had little representation in government despite their large numbers. The white rulers also ensured that "income taxes and inheritance taxes and real estate taxes are nonexistent," relying on sales taxes for revenue. Because the elite was so miserly, moreover, "the educational system is none too good." Friedman's depiction of Bermuda could have been applied to the mid-1950s U.S. South, too. But by some alchemy of the libertarianism he had since imbibed, voter suppression, regressive taxation, and inferior schools for Black citizens no longer troubled him as they had before he saw the light. Friedman and Friedman, Two Lucky People, 67, 81. Friedman professed to be shocked, looking back, at "how thoroughly Keynesian I was then" (11).
} 
individual "tastes and values." On the contrary, an entire social order entrenched this racial discrimination, in which whites maintained their edge by law, practice and force. The ruling was in Solo's view "an important instrument" to alter "attitudes" and policies that had "blight[ed]" society and blunted "economic progress in the region and the nation at large." Under these conditions, it was a fantasy to speak of "free choice" in schools. If Friedman sought to exalt choice as a supreme value, did he not have a responsibility to address the radically unequal power of the putative choosers? ${ }^{26}$

But Friedman would have none of it; he lashed back hard, in a way that hinted at how calculated his intervention had been. Known for being a "bulldog" in debate, he did not bother to contest Solo's depiction of the conditions that led the Supreme Court to find violation of the constitutional guarantee of equal protection. Instead, he tried to put his critic on the defensive. "How in principle," Friedman demanded, did Solo propose to distinguish between the court's "forcing this particular change in the context of tastes and values and those which, for example, Hitler wanted to enforce?" Hitler? Claiming that any government attempt to stop discrimination against a whole group of Americans was indistinguishable from the lethal "tastes and values" enforced by the Nazi regime seemed elementary to Friedman. ${ }^{27}$ To him it seemed logical that you could not enforce civil rights without risking a police state. That imaginary risk alarmed him. The reality of generations of grossly inferior schools for disenfranchised Black citizens did not.

III

Whether or not Friedman had Dixie in mind as he drafted his article, he indisputably did all he could to take advantage of the opening created in early 1956 when southern states began "massive resistance" to Brown. Friedman's voucher manifesto introduced a third

\footnotetext{
${ }^{26}$ Robert Solo to Milton Friedman, Oct. 12, 1954, box 33, Friedman Papers. For empirical proof of Solo's case that civil rights reform fueled economic development that benefitted all Southerners, whites as well as Blacks, see Gavin Wright, Sharing the Prize: The Economics of the Civil Rights Revolution in the American South (Cambridge: Harvard University Press, 2013).

${ }^{27}$ Milton Friedman to Robert Solo, Oct. 15, 1954, ibid. "As a debater," one historian notes, Friedman "was skilled at shifting discussions away from points of potential weakness in his argument and toward evident flaws in the ideas expressed by his opponents." Angus Burgin, The Great Persuasion: Reinventing Free Markets since the Depression (Cambridge: Harvard University Press, 2012), 163.
} 
option beyond the two that other Americans saw: segregate or integrate. His case enabled evasion of that choice, by endorsing the call of diehard segregationists to use tax revenues to subsidize private schools beyond the reach of Brown: essentially, to have state monies pay for schools that would exclude Black children for those whites who wanted them. Crucially, he did so in race-neutral language that could survive court review - at least over the first formative decade. Drawing on his case against government-run schools, savvy segregationists discovered that they could depict themselves as devotees of educational freedom. Leading advocates of segregation increasingly shifted from white supremacist arguments to the neoliberal language of liberty, competition, and market choice.

As Virginia's General Assembly considered shifting from its initial plan for compliance with Brown (albeit grudging compliance designed to minimize integration) to the proposed policy of massive resistance over the fall of 1955 into 1956, Friedman's manifesto provided guidance to some segregationists in the trenches. One site of sharp struggle was Northern Virginia, home to the expanding Washington, D.C. suburbs whose residents were deeply committed to public education and relatively open to desegregation. Leading the attack on desegregation plans was Harley M. Williams, president of a newly created Fairfax County group called the Virginia Committee for Better Schools. Williams despised the very idea of public education, blaming its emergence in Virginia in 1870, during Reconstruction, on what he called "a carpetbagger legislature, backed by Federal bayonets." In October of 1955, his organization held a public forum featuring Dr. Mollie Ray Carroll, a Chicago-trained economist and Fairfax resident, to urge that the state subsidize private schools. The plan they put forward followed Friedman's almost to the letter. Virginia would pay "allowances" (vouchers) to the parents of children attending accredited private schools. Critics were pointed toward the 1944 G.I. Bill. Williams said, "this proposal is to help preserve and extend freedom," to enable true school "choice." 28

\footnotetext{
${ }^{28}$ Harley M. Williams, "Virginia School Proposal," Washington Post and Times Herald, Oct. 16, 1955, E4; Mollie Ray Carroll to James J. Kilpatrick, March 21,1956, James Jackson Kilpatrick Papers, Accession 6626-B, University of Virginia Special Collections Library, Charlottesville, VA. I thank James H. Hershman, Jr. for supplying me with sources on Williams and Carroll—and so much more Virginia history knowledge
} 
Friedman's framing proved exceedingly helpful to Williams, whose earlier efforts had been clumsier. Six months before, he had co-led a group of about a hundred protesters who succeeded in shutting down a public meeting convened by the local Parent-Teacher Association and the Virginia Council of Churches to discuss how best to carry out school integration. "With loud booing and hissing," Williams and his colleagues "charged from the floor that the meeting had been 'packed' with 'pro-integrationists." The men started a "bitter fight." At wit's end after an hour of wrangling, the mother chairing the meeting removed her shoe and gaveled the table to try to restore order, to no avail. The Williamsled group "[took] over the hall for a white-supremacy mass meeting," reported a veteran journalist. ${ }^{29}$ Clearly, the segregationists needed a more appealing strategy. Thanks to the University of Chicago economist, they got one.

With all the publicity, signature Friedman ideas peppered the letters pages of the northern Virginia press by December. One local couple urged readers to consider how school vouchers would give parents the "choice" to escape the "government ... monopoly," as well as spend more for their own children in a "competitive education industry." ${ }^{30}$ A Falls Church man told voters it was high time to end the "monopoly regimenting [of] the minds of our youth." Harley Williams urged that Virginia must cease worshipping "that sacred cow, the public school system." Its residents needed the "liberty" that would come from "making it economically possible for parents and guardians to have a choice" of where to send their children to school. Still, Williams lacked the discipline to adhere to color-blind language. Anyone who voted against the vouchers, he blurted out in making his case, would "compel the exposure of white children to the lower health and moral standards of the Negro race" with the "risk of increased intermarriage and amalgamation." 31

\footnotetext{
29 “Integration Foes Boo Fairfax P-TA, Take over Workshop Meeting Hall," Washington Post and Times Herald, May 1, 1955, A1; Benjamin Muse, “'Defenders' Trample True Traditions," Washington Post and Times Herald, May 8, 1955, E2.

${ }^{30}$ Stephen P. Taylor and Natalie B. Taylor, "Aid to Private Schools," Washington Post and Times Herald, Dec. 9, 1955, 18.

${ }^{31}$ Samuel E. McCrary, “Challenge in Virginia," Washington Post and Times Herald, Dec. 12, 1955, 18; Harley M. Williams, "The Gray Proposal: Pro and Con,” Dec. 18, 1955, ibid. As today, such culture war race-baiting served instrumental ends. "The real fear of politicians in Virginia," explained the state NAACP president E.B. Henderson, "is not of miscegenation, health hazards, [and] lower school standards," but rather "that Negroes will become political and begin to vote." Hershman, "A Rumbling in the Museum,"
} 
Friedman himself kept tabs from afar, so he could help. Soon after a referendum passed in January of 1956 allowing taxpayer funds to go to parents who wanted to send their children to non-sectarian private schools, Friedman mailed copies of his manifesto to his friend Emerson P. Schmidt, the longtime Director of Research for the U.S. Chamber of Commerce and a resident of northern Virginia. A like-minded economist who often testified in Congress against labor laws and the minimum wage, Schmidt sent off letters to the editors of several Virginia newspapers, citing Friedman's rationale for this core measure of massive resistance. "Entirely apart from any question of segregation," Schmidt wrote, "in these days of increasing intervention by government in our affairs, we should never overlook an opportunity to expand private effort wherever it can do the job." He urged advocates of tax subsidies for segregation academies to read Friedman's article, for "here you will find a different argument in keeping with the philosophy of freedom and free enterprise for the policy which you endorse." 32

As states across the South laws passed laws enabling private school vouchers, Friedman pressed his case. In June of 1957, he was a featured speaker at a ten-day Conference on Political Economy at the University of North Carolina that was underwritten by a rightwing donor to promote an anti-government worldview among "young academics" in the region. ${ }^{33}$ The goal of his three lectures, he told the younger men, was to demonstrate how nineteenth-century British political economy, with its "emphasis on individual freedom and absence of state intervention" could be applied to "specific problems of policy." A case in point was "segregation in education." He argued that any "enforced" system violated liberty. His lecture notes read: "Appropriate solution is privately operated

53-54, 204, 214. And, indeed, there was worry that "Negro registration has been very heavy" in Richmond. Sam M. Jones, "Tidewater State Leads South in Seeking Way out of the Desegregation Crisis," National Review, Dec. 28, 1955, 23.

32 Emerson P. Schmidt to Milton Friedman, Jan. 16, 1956, box 32, Friedman Papers; Schmidt to Loudon Times-Mirror, Jan. 16, 1956, ibid; same to Washington Post and Times Herald, Jan. 29, 1956, E4; Schmidt to Garland Gray, Jan. 16, 1956, ibid. The association between Friedman and Schmidt went back several years, as the file shows. I thank James Hershman for alerting me to Schmidt and sharing his letters to editors and biography.

${ }^{33}$ Friedman and Friedman, Two Lucky People, 338-340. 
school system with parent choice of schools." He assigned his manifesto as suggested reading. ${ }^{34}$

No transcript of the discussion survives, but among the attendees was Friedman's first Ph.D. student, G. Warren Nutter, who had just joined the faculty at the University of Virginia in Charlottesville. During the closing session of the gathering, Nutter reported that his wife, who had been listening in silence to the assembled men's conversations, commented that perhaps the assembled scholars failed to understand "what Mr. Friedman was saying" about the public schools: "he wants to disintegrate them." A prospect that horrified her apparently amused him: chaos, it seemed, was the price of freedom. Nutter composed a playful parting "poem" for his comrades: "With arguments moralistic/and illogically negativistic/We've launched a new liberal tradition/Of freedom of disintegration." ${ }^{35}$ Freedom of disintegration: however fortuitously, the phrase captures the impact of Friedman's ideas on public life.

By early 1958, the neoliberal rationale found a local fan with the time and money to focus nearly full-time on the issue for the next few years. A former journalist and newspaper editor who had retired to an estate near Charlottesville, Leon Sebring Dure became a veritable one-man think-and-act tank aiming to steer segregationists away from their overt white supremacist case for vouchers and toward an ostensibly color-blind case about individual liberty. He saw that openly racist vouchers would never survive court review. "Somebody has got to find a rabbit in an empty hat-NOW," Leon Dure warned James (Jack) Kilpatrick that spring. "If we wait much longer the jig will be up .... forever!" The future of segregation teetered on a knife's edge. As the most astute advocate of massive resistance from his post as editor of the daily Richmond News Leader, Kilpatrick knew that state governments needed private schools to evade Brown, a

\footnotetext{
${ }^{34}$ Milton Friedman, "Titles and Brief Outlines of Lectures to be Given at North Carolina College [sic]," June 1957, box 216, Friedman Papers.

${ }^{35}$ Conference on Political Economy, Chapel Hill, June 1957, "Thoughts of Participants at the End of the Conference," box 203, Friedman Papers. Friedman also assured that the market would end employment discrimination because, according to his theory, it was costly. Capitalism had been a "major source of emancipation of [the] Negro," he claimed (ignoring plantation slavery as a top source of capital accumulation in the era whose political economy he held up as a model of liberty). The proper approach to discrimination was not "interference with [white] freedom" but to "to persuade our fellow men." Friedman, "Titles and Brief Outlines."
} 
project that could not go forward without state subsidies. Too many white families could not or would not pay private school tuition from their own pockets; that fact was the Achilles' heel of the segregationist dream of white solidarity. And when the courts recognized that public monies were subsidizing defiance of Brown, as they surely would sooner or later, the judges would stop the flow. "To have private schools," Dure insisted, the state must have vouchers not tied explicitly to segregation and in theory available to all parents--though their purpose was to enable segregation academies and everyone knew Blacks opposed and boycotted them. ${ }^{36}$

"Freedom is the answer," Dure exulted as he pushed repackaging to what he called "freedom of choice of association," later shortened to freedom of choice. A white supremacist, Dure served as the chief fundraiser for two segregated private schools in Charlottesville, one named after the Confederate General Robert E. Lee. "The Negro high school would become the public, non-segregated school," he envisioned, and "the White school would be run private privately on tuition money from the city and the state." "The freedom of the marketplace," he told Kilpatrick, "solves all our problems." ${ }^{37}$ In fact, Dure tutored, "the only way to get rid of compulsory integration was to erect the old marketplace right of free choice." By mid-March of 1959, Kilpatrick agreed that "a 'freedom of choice' plan" would enable "those of us who believe in segregated schools for our children [to] see that they have lawfully segregated schools to go to." ${ }^{38}$

Black Virginians saw the "rabbit in a hat" solution for what it was: tax-subsidized racism with a color-blind façade. "Please tell me," demanded a Charlottesville man who had wearied of Dure's incessant hectoring about freedom of choice: "why we should pay the segregationists to go to their segregationist schools"? ${ }^{39}$ On the contrary, a Black editor

\footnotetext{
${ }^{36}$ Leon Dure to James Kilpatrick, May 26, 1958, box 1, series JKM, Kilpatrick Papers; Dure to Kilpatrick, March 20, 1959, ibid; see also Dure's paid ad “A Plan of Action," Richmond Times Dispatch, Jan.20. 1958 and privately printed pamphlet: Leon Dure, "A Way out of Our Dangerous School Situation," (Keswick, VA, 1958), box 2, Dure Papers.

${ }^{37}$ Leon Dure to Kilpatrick, May 26, 1958, box 1, series JKM, Kilpatrick Papers; Dure to James J. Kilpatrick, Aug. 5, 1961, ibid; Dure to Kilpatrick, May 18, 1959; Janet W. Miller to Leon Dure, Sept. 25, 1961, box 3, Dure Papers; Andrew Ziet Glickman, "Virginia Desegregation and the Freedom of Choice Plan: The Role of Leon Dure and the Freedom of Association" (M.A. Thesis, University of Virginia, 1991), 97-98.

${ }^{38}$ Kilpatrick to Gravatt, March 16, 1959, box 1, Gravatt Papers.

${ }^{39}$ Lester A. Beaurline to Leon Dure, March 30, 1964, box 4, Dure Papers.
} 
told Dure, any parent who wanted to patronize private schools should "dig down into his own pocket." 40 Oliver Hill, the NAACP attorney who had co-led Virginia's piece of the litigation folded into Brown, put the principle in an apt axiom: "No one in a democratic society has a right to have his private prejudices financed at public expense." $" 41$

So, too, E. B. Henderson, a state NAACP official, politely spurned Dure's letters seeking to win his assent to a policy designed to evade the organization's victory in court. The NAACP was "willing to accept" a good-faith transition that might take some time, Henderson said. And of course, any child was free "to leave the public school for a private school." But providing public subsidies for bigots was something else again. Why not recognize "that de-segregation could be a boon to white children," because "the majority of the people of the world are so-called colored people"? "As the world shrinks," he foresaw, all children "will be badly adjusted unless they learn early to recognize individuals for what they are other than by the color of their skins or race or nation." By attending the same schools, they could "learn to live with each other on a basis of mutual respect." 42 But Dure turned a deaf ear to critics.

Dure's systematic articles, letters to editors, hearing testimony, and private correspondence with influential whites paid off. He even won over some leading massive resisters to the new framing. "I can't see anything in the Dure plan that is in conflict with what the Defenders are trying to do," concluded the local president of the Charlottesville Defenders of State Sovereignty and Individual Liberties. ${ }^{43}$ "It is amazing the change that has occurred in one short year, all of it due, it seems to me, to the power of words and semantics," Dure boasted to the state attorney general. "The Defenders up here, like the [General] Assembly, are now entirely willing to give up segregation by law in a swap for the individual freedom of association." 44 Having triumphed with the "swap" at home,

\footnotetext{
${ }^{40}$ Randolph L. White to Leon Dure, box 3, Dure Papers.

${ }^{41}$ Oliver Hill quoted in Hershman, "A Rumbling in the Museum," 129.

42 E.B. Henderson to Leon Dure, Jan. 6, 1959, box 3, Dure Papers; see also Oliver Hill to Dure, Jan. 15, 1960 , ibid.

43 Pamela Jane Rasche, "Leon Dure and the 'Freedom of Association."' (Unpublished thesis, University of Virginia, 1977), 46.

44 Dure to Albertis Harrison, April 4, 1959, box 1, Dure Papers.
} 
Dure went on to evangelize elected officials in other southern states and testify in their legislative hearings on behalf of the new framing. ${ }^{45}$

Friedman helped Dure reach a broader constituency by providing him with contacts. One was Roger Freeman, an economist affiliated with the American Enterprise Association (now the American Enterprise Institute), who served on the National Tax Association's Committee on Financing of Public Education. ${ }^{46}$ In a 1955 pamphlet Freeman had challenged: "Who is going to pay the taxes needed to finance the ambitious [educational] programs which are being proposed?," He referred, no doubt, to the rise of mandatory high school, which meant that more young people — particularly boys — were attending school beyond the $8^{\text {th }}$ grade. Similarly, Black Americans were organizing for equal access to better schools, including high schools. And public higher education enrolled growing numbers after World War II and the Korean War, many veterans among them. ${ }^{47}$ "No nation has ever attempted to keep so many children in school so long," Freeman worried in print. ${ }^{48}$

The prospects for weakening support for public education appeared so promising that Dure invited Friedman to visit Charlottesville for a joint meeting with G. Warren Nutter and James M. Buchanan, the economics professors who were helping promote the voucher cause from their perch at the University of Virginia. Friedman arrived in April of 1960 and gave a public lecture on the economics of education, followed by a meeting

\footnotetext{
${ }^{45}$ Dure to Kilpatrick, Feb. 13, 1959, box 1, ibid. For the full record of Dure's shrewd strategizing, writing, and traveling to maintain as much segregation as possible, see Dure Papers. For a brief biography that identifies his pivotal role, see James H. Hershman, Jr., Leon S. Dure (1907-1993), Encyclopedia of Virginia: https://encyclopediavirginia.org/entries/dure-leon-s-1907-1993. Louisiana and Georgia adopted the tuition grant laws most similar to Virginia's. See Leon Dure, "In General Explanation," p. 10, Box 1, Leon Dure Papers, University of Virginia Special Collections Library, Charlottesville, VA; Staige D. Blackford, "Free Choice and Tuition Grants in Five Southern States," New South, April 1964, 3, 13. ${ }^{46}$ Milton Friedman to Leon Dure, Dec. 6, 1960, box 25, Friedman Papers; National Tax Association's Committee on Financing of Public Education committee membership roster, Dec. 11, 1958, box 346, Roger Freeman Papers, Hoover Institution.

${ }^{47}$ Roger A. Freeman, Federal Aid to Education - Boon or Bane? (Washington, D.C.: American Enterprise Association, 1955); National Tax Association's Committee on Financing of Public Education, committee membership roster, Dec. 11, 1958, box 346, Roger Freeman Papers, Hoover Institution.

${ }^{48}$ Roger A. Freeman, "Unmet Needs in Education," typescript report for the Volker Fund, July 15, 1959, pp. 2, 16, 25, 28, in box 311, Roger Freeman Papers, Hoover.
} 
with Dure. ${ }^{49}$ According to the latter's thrilled account, "educationists' views" (that is, the concerns of voucher opponents) were "openly ridiculed" by "the economists." 50 Soon thereafter, the editor of the largest circulation newspaper in the state, the Norfolk Virginian-Pilot, lambasted Dure's arguments. Lenoir Chambers called out Dure for seeking "to belittle public education" and tar it as a "state-run monopoly" of 'socialistic' background and character" in his campaign to evade desegregation. "S1 "Socialistic" was to libertarians then, as it is to neoliberals now, a synonym for all public services and resources; its disrepute in the Red Scare era no doubt helped.

Later that year, Friedman alerted Dure to a group of Catholics who were seeking vouchers for parochial schools. ${ }^{52}$ In St. Louis, they had founded Citizens for Educational Freedom (CEF) in 1959 to promote the "God-given and inalienable right" of "parents to direct and control their children's education" by getting their "fair share" of tax monies. The organizers insisted that their cause was non-sectarian and they reached out to Protestants and Jews. Yet Catholics predominated because, as one CEF leader joked privately, "we papists maintain the bulk of the private schools in this so-called Democracy." Within a few years, CEF claimed a membership of 20,000 and 70 chapters in 21 states. $^{53}$

Dure struck up a regular correspondence with CEF leaders, who ordered 500 reprints of his articles to give to "about all the bishops there are" and over two hundred newspapers

49 Dure to Friedman, March 29, 1961, box 25, Friedman Papers; G. Warren Nutter to Friedman., Feb. 18. 1959, box 31; Friedman to Nutter, Jan. 30, 1960G. Warren Nutter to Dure, Feb. 24, 1960, box 1, Dure Papers.

${ }^{50}$ Dure to Francis P. Miller, May 8, 1960, box 1, Dure Papers; "CEF to Launch Fund Drive" (announcement of Dure as chair) Daily Progress, April 20 1960, p. 13; "Dure Says CEF Fund Drive Is to Establish Freedom Here," April 27, 1960, p. 17.

${ }^{51}$ Lenoir Chambers, Editorial: "To a Champion of the Tuition Grants," Norfolk Virginian-Pilot, July 30, 1960. Chambers's work on massive resistance earned him a Pulitzer Prize for Distinguished Editorial Writing in 1960.

${ }^{52}$ Milton Friedman to Leon Dure, Dec. 6, 1960, box 3, Dure Papers. Parochial schools faced crisis as millions of Catholics moved to the suburbs and costly construction needs entailed tax levies that left parents less willing to pay tuition for their children. John T. McGreevy, Parish Boundaries: The Catholic Encounter with Race in the Twentieth-Century Urban North (Chicago: UCP, 1996), 234-47.

${ }^{53}$ Citizens for Educational Freedom, "Parent's Civil Rights in Education" brochure, [ca. 1962] in box 45, Part 1, Daniel P. Moynihan Papers, Library of Congress, Washington, DC; Nov. 27, 1964 Memo to Secretary of Labor, Nov. 27, 1964, ibid.; Vincent P. Corley to Leon Dure, May 24, 1961, box 4, Dure Papers. 
and magazines. ${ }^{54}$ Need drew the two parties together. Dure and his fellow segregationists required support from Northerners to prevail with their "freedom of choice" argument, while the Catholics wanted support from Southerners to secure financial aid from Congress. "If the South wins its fight for the freedom of assembly (association) in education you shall win yours too," Dure promised. .5 "On both sides of the regional fence," agreed the Brooklyn-based CEF attorney Joseph Danahy, "we have a lot of selling to do...to solve what is basically a common problem." 56

As voucher advocates bonded across regional and denominational lines, southern defenders of public education and advocates of desegregation saw the potential for social disintegration. Eugene Patterson, the white editor of the Atlanta Journal-Constitution, warned Dure: "We don't have the money even now to run a decent public education system. I dread to think of what condition our lower classes would retreat to if we now attempt to weaken this public schooling by dividing an already anemic effort." Although Patterson had long sent his own daughter to a private school, he found ludicrous the libertarian claim that private school parents suffered discrimination, as payers of tuition and taxes for public education. "I will never embrace the philosophy," he replied, "that what I can do for myself frees me from my responsibility to people who can do less." Thus, he explained, "I don't mind paying taxes for other people's schools" because "that's what democracy is all about": "a willingness to help our brothers."

\footnotetext{
${ }^{54}$ Corley to Dure, Jan. 12, 1962, box 4, Dure Papers.

${ }^{55}$ Leon Dure to Virgil Blum, Dec. 21, 1961, box 1, series 2, subseries 4, Blum Papers; Vincent P. Corley to Leon Dure, Jan. 20, 1962, box 4, Dure Papers. Privately, Dure concluded "that this CEF bunch is our best bet. After all, they control a sizable bloc in the House.” Dure to J. Segar Gravatt (the attorney for Prince Edward County), June 11, 1964, box 2, Gravatt Papers.

${ }^{56}$ C. Joseph Danahy to Dure, Jan. 23, 1962, box 4, Dure Papers. They enjoyed a victory when a New York Democratic congressman, James J. Delaney, joined with Republicans and southern Democrats on the House Rules Committee in 1962 to table federal aid to education that failed to provide "freedom of choice." Citizens for Educational Freedom, "Battle for Children's Minds," newsletter [1962] in box 45, Part 1, Daniel P. Moynihan Papers; also see Nov. 27, 1964 Memo to SOL, Nov. 27, 1964, ibid.

${ }^{57}$ Eugene Patterson to Leon Dure, Feb. 27, 1961, Box 3, Dure Papers; Dure to Kilpatrick, March 25, 1960, box 1, series JKM, Kilpatrick Papers. Another key critic of Dure and the vouchers was the dean of University of Virginia Law School: Hardy Cross Dillard, "Freedom of Choice and Democratic Values," Virginia Quarterly Review 38 (Summer 1962), 410-35.
} 
IV

The libertarian cause rejected such social solidarity from the outset. That is part of why so many advocates saw great promise in what Virginia was doing, and why some provided practical assistance to expand private schooling in the South, whatever the damage to Black citizens. Both libertarian thinkers and leaders of some of the institutions that first built up the neoliberal cause lauded the white South's turn to private schools, as this section will show. They saw no problem with tax subsidies to segregation academies, even in states that denied voting rights to African Americans harmed by the policy. Some libertarians even cheered on the backlash, seeing its potential to expand their ranks.

Murray Rothbard, an acolyte of the Austrian economist Ludwig von Mises and freelance writer later funded by Charles Koch, cheered the prospect of privatizing a core element of the public sector he so despised. Rothbard had already voted in 1948 for the Dixiecrat presidential candidacy of South Carolina's Strom Thurmond, since he agreed that federal action against segregation violated states' rights. "I used to think that we were the 'true liberals," Rothbard reflected in 1956 on the claim of many of his fellows to be "classical liberals," but in truth, nineteenth-century liberals such as John Stuart Mill were "great advocates of democracy and majority rule" and "adherents of the public school system." Libertarians were at odds with classical liberals on these vital issues, and Rothbard recognized that in claiming that name, libertarians sailed under a false flag. ${ }^{58}$

Like Rothbard, Robert LeFevre hailed the developments in Dixie. This libertarian trailblazer exulted that "the segregation decision" could bring "a realignment" of American politics, as “an aroused and embittered [white] South" found allies among Northerners long hostile to the New Deal. ${ }^{59}$ Soon after Virginia's massive resistance package passed, LeFevre founded the Freedom School in Colorado that tutored visitors in a veritable anarchist version of capitalism, with visiting teachers including F.A. Harper, Gordon Tullock and Ludwig von Mises. It became a favorite destination of Milton and

\footnotetext{
${ }^{58}$ Doherty, Radicals, 245, 258-9, 285-6. Rothbard called the Social Darwinist tract Social Statics, by Herbert Spencer, "the greatest single work of libertarian philosophy ever written." (246)

${ }^{59}$ Robert LaFevre to Jack Kilpatrick, July 1, 1954, acc. 6626-b, Kilpatrick Papers; same to same, July 6, 1954, with attachment, ibid.
} 
Rose Friedman, who modeled their own vacation home on its lodge. Charles Koch outdid them in enthusiasm by becoming a top funder and trustee. LeFevre promised that the Freedom School would teach that "our government schools have failed us," a cause also important to Koch. ${ }^{60}$

The writer Isabel Patterson, an avid advocate of unfettered (white) liberty who is still celebrated by the Koch-founded and funded Cato Institute, made a similar case. ${ }^{61}$ As the massive resistance laws loomed, Patterson opined that "a tax-supported, compulsory educational system is the complete model of the totalitarian state." She cheered the white South's stand for states' rights, saying it might help overthrow the "monstrous bureaucracy" in Washington, D.C. that had come of "an unqualified electorate voting." More strikingly, the Mont Pelerin Society - the core nexus of the intellectuals and business donors driving neoliberalism then and now - had several members with telling connections to southern white reaction. In his first year on the faculty at the University of Chicago, Friedman had been among the founders of the Society, the goal of which was as grand as the earlier dreams of Thomas Paine or Karl Marx: to alter the tide of history. Some three dozen scholars, journalists, foundation officials, and businessmen from the United States and Western Europe converged in that year in Switzerland. They came in answer to a call from the Austrian-born scholar, Friedrich Hayek, who three years before had published a surprise hit, The Road to Serfdom. ${ }^{63}$ Pitting himself against “collectivism," Hayek had insisted that "personal and political freedom" depended on

\footnotetext{
${ }^{60}$ Robert LaFevre to Jack Kilpatrick, April23, 1956, with attachments, acc. 6626-b, ibid.; Kilpatrick to LeFevre, April 26, 1956, ibid. On Koch's enthusiasm for the Freedom School, see Daniel Schulman, Sons of Wichita: How the Koch Brothers Became America's Most Powerful and Private Dynasty (New York: Grand Central Publishing, 2015); Jane Mayer, Dark Money: The Hidden History of the Billionaires Behind the Rise of the Radical Right (New York: Doubleday, 2016). On Koch's Center for Independent Education, see MacLean, Democracy in Chains, 133.

${ }^{61}$ Ayn Rand, a mentee, said that Patterson's 1943 book, The God of the Machine, "does for capitalism what Das Kapital does for the Reds and what the Bible did for Christianity." Doherty, Radicals for Capitalism, 114-120, 122, 125; for the Cato Institute's tribute to Isabel Patterson, see http://www.libertarianism.org/publications/essays/isabel-paterson, downloaded April 25, 2014.

${ }^{62}$ Isabel Patterson, "The Southern Breakthrough,” National Review, Dec. 21, 1955, 9-12.

${ }^{63}$ Friedman and Friedman, Two Lucky People, 158-161; Richard Cockett, Thinking the Unthinkable: ThinkTanks and the Economic Counter-Revolution, 1931-1983 (London: HarperCollins, 1995), 110; Philip Mirowski and Dieter Plehwe, The Road from Mont Pèlerin: The Making of the Neoliberal Thought Collective (Cambridge: Harvard University Press, 2009).
} 
"freedom in economic affairs." To him, the New Deal form of government in America was as threatening to liberty as the recently defeated fascist states in Europe and the current spread of Communism. ${ }^{64}$ The Society he and the others founded took up the case against this threat. After an extended visit to the University of Virginia, Hayek endorsed Virginia's tuition grants. ${ }^{65}$

Another Mont Pelerin Society co-founder, the Pulitzer Prize-winning journalist Felix Morley, went further. "From the day of the Supreme Court's unanimous ruling against racial segregation in the public schools," Morley wrote, the "resurgence of [a] political movement on behalf of States' Rights became probable." That movement inspired Morley's own contribution to the cause, a book called Freedom and Federalism, which also endorsed Virginia's policy. Looking South, Morley anticipated "over large areas, abandonment of public education as a State function." 66

Henry Regnery, yet another Mont Pelerin Society stalwart, joined the chorus. His aid to the movement was publishing rightwing books and fundraising. Thus, he urged the journalist Jack Kilpatrick to write up a book-length case for states' rights and private schooling. ${ }^{67}$ The Sovereign States, released in 1957, drew praise from advocates of economic liberty on both sides of the Mason-Dixon Line. And no wonder: its forceful brief against federal power took aim not only at the Brown decision, but also the high court's interpretation of the Constitution's Commerce Clause, which had enabled so much federal regulation since 1937. Kilpatrick argued that the signature achievements of the New Deal--the Wagner Act, the Social Security Act, and the Fair Labor Standards Act--were all as unconstitutional as the Brown desegregation decision. ${ }^{68}$ In short, for him

${ }^{64}$ F. A. Hayek, The Road to Serfdom (1944; reprint, Chicago: University of Chicago, 1994), 13, 16, 17, 19

${ }^{65}$ F. A. Hayek to Ivan Bierly, Feb. 2, 1961, box 57, Friedrich A. von Hayek Papers, Hoover Institution Archives; Leon Dure to Segar Gravatt, June 4, 1964, box 2, John Segar Gravatt Papers, Special Collections Library, University of Virginia, Charlottesville, VA.

${ }^{66}$ Felix Morley, Freedom and Federalism (Chicago: Henry Regnery Company, 1959), 171, 187, 190, 194.

${ }^{67}$ Regnery to Kilpatrick, May 19, 1955, box 39, Henry Regnery Papers, Hoover Institution Archives, Stanford University, Palo Alto, CA. At Regnery's publishing house, the college editor urged an education critic to be less "genteel"; they could get "vastly more sales" with "an title" like "America's Public School Is America's Public Enemy." Sidney Russell to Mortimer Smith, Aug. 15, 1955, box 69, Regnery Papers. Smith declined the red-meat title. Mortimer Smith, ed., The Public Schools in Crisis: Some Critical Essays (Chicago: Henry Regnery, 1956).

${ }^{68}$ Henry Regnery to Kilpatrick, March 14, 1956, box 66, James J. Kilpatrick Papers, Acc. B; James Jackson Kilpatrick, The Sovereign States: Notes of a Citizen of Virginia (Chicago: Henry Regnery Company, 1957), 
as for his new allies, taking down the New Deal and stopping federal action to ensure equal treatment for Black Americans were one and the same project.

Just as many early writers and theorists in the libertarian cause embraced the vouchers that funded segregationist schools, so did figures in some of the other founding institutions of neoliberalism that survive, at least in some form, today. Take, for example, the Foundation for Economic Education (FEE), a New York-based organization which prides itself on being the longest-lasting think tank in America devoted to "the freedom philosophy" of unrestrained capitalism. It has provided a platform for a who's who of libertarian economists over the years, and has given distinguished alumni awards to figures including Edwin Feulner, the founder and longtime president of the Heritage Foundation, and Charles Koch, the CEO of Koch Industries, who has given FEE an untold sum over the years." 69

Among FEE's trustees were two influential Virginia segregationists who understood the need for a more libertarian, pro-market packaging of the cause. One was John Dana Wise, the publisher of the Richmond News Leader, which hosted Jack Kilpatrick's editorializing in defense of Jim Crow and support of massive resistance. It was Wise, along with Senator Byrd, that the ambitious Kilpatrick aimed to please. "Every time I let a liberal impulse escape in print," Kilpatrick recalled of his first years at the News Leader, Wise "summoned me into his office" for a "line-by-line" take down. But Wise also warned Kilpatrick about his hot-headedness and use of racial stereotypes, warning that "we must adapt ourselves to changing weapons and to changing tactics. I do not propose to win a battle, and to lose the war."70 Another FEE trustee was the Charlottesville-based attorney Donald Richberg, author of Labor Union Monopoly and a passionate advocate of "right to work" laws. Richberg had earlier condemned "Civil

\footnotetext{
234-251. For Regnery's pride in the book and its role years later, see Regnery to Kilpatrick, April 17, 1972, box 39, Regnery Papers.

${ }^{69}$ On Koch funding, see https://www.greenpeace.org/usa/ending-the-climate-crisis/climate-deniers/frontgroups/foundation-for-economic-education-fee/

${ }_{70}$ Philip J. Hilts, "The Saga of James J. Kilpatrick." Potomac magazine of the Washington Post, Sept. 16, 1973; William P. Hustwit, James J. Kilpatrick: Salesman for Segregation (Chapel Hill: University of North Carolina Press, 2013), 29-32, 38-40; Leonard E. Read to T. Coleman Andrews, May 10, 1949, box 4, T. Coleman Andrews Papers, Division of Special Collections, University of Oregon Libraries.
} 
Rights Hysteria" for wartime federal equal employment measures, demanding "does freedom to associate include freedom not to associate?"- precisely the case that Leon Dure would make. After Brown, he assisted his fellow massive resisters, including Jack Kilpatrick, with strategy in their quest for court-proof private school tuition vouchers. ${ }^{71}$

The William Volker Fund, which helped underwrite the Mont Pelerin Society, also aided school privatization in Dixie. Here the groundwork for our own time is even more direct. Both insiders and scholars agree that without the Volker Fund there would be no neoliberal movement. The foundation subsidized the academic salaries of Friedrich Hayek at the University of Chicago, Ludwig von Mises at New York University and Aaron Director, the founder of the field of law and economics so foundational to today's antiregulatory cause (and brother of Friedman's spouse, Rose), at the University of Chicago Law School. Volker also paid travel costs for Americans to attend the Mont Pelerin Society's European meetings. ${ }^{72}$ And it invested in other libertarian scholars and projects beyond number. It was, moreover, the lineal progenitor to today's Institute for Humane Studies, a core organization in the academic talent pipeline funded by the Charles Koch Foundation, which trolls universities for prospects using cash as bait. ${ }^{73}$ The Volker Fund was eager to sink roots in the South in the late 1950s as enmity to the federal government was growing there. The foundation funded the 1957 UNC conference for young academics where Milton Friedman pressed his case for vouchers. It underwrote the first five years of the southern outpost of the neoliberal cause set up at the University

\footnotetext{
${ }^{71}$ Italics mine. Quotes and information from James H. Hershman, Jr., "The Wayward Liberal" and Virginia's Massive Resistance: Donald Richberg, Libertarian Economics, and Militant Segregation," unpublished article in the author's possession.

72 Phillips-Fein, Invisible Hands, 41-2; Rob van Horn and Philip Mirowski, "The Rise of the Chicago School of Economics and the Birth of Neoliberalism," The Road from Mont Pelerin: The Making of the Neoliberal Thought Collective, ed. Philip Mirowski and Dieter Plehwe (Cambridge: Harvard University Press, 2009), 139-168; Lanny Ebenstein, Milton Friedman: A Biography (New York: Palgrave Macmillan, 2007), 139.

${ }^{73}$ See Michael McVicar, "Aggressive Philanthropy: Progressivism, Conservatism, and the William Volker Charities Fund," Missouri Historical Review 105, n. 4 (2011), 201. For a more appreciative view of Volker, see Doherty, Radicals for Capitalism. For a trove of historical documents on IHS, see the website Koch Docs: https://kochdocs.org/?s=\%22institute+for+humane+studies $\% 22$

For current Koch campus spending, see UnKoch My Campus, "Increased Spending, Increased Influence," May 2021: http://www.unkochmycampus.org/funding-report.
} 
of Virginia by the Chicago alumni G. Warren Nutter and James Buchanan. ${ }^{74}$ Volker also funded bulk purchases of Kilpatrick's book, The Sovereign States, for distribution to some 1,200 college libraries and 260 private schools. It also planned an educational outreach "program for selected editors."75

With Friedman's assistance, the Volker Fund aided the Charlottesville team trying to spread private schooling. Friedman joined the meeting with Ivan Bierly of Volker when he came to town to get the lay of the land. ${ }^{76}$ Volker also sent James W. Kirchanski, who recently had founded a chain of for-profit schools called "3R," to Virginia to explore the prospects with advance notice that "he is 'death' on what is going on in public schools and isn't afraid to say so." "Th "Should the NAACP get aggressive this coming fall" in pushing desegregation in Richmond and other areas, Dure gloated to Kilpatrick, "it is just possible that something like the $3 \mathrm{R}$ schools could save the day." 78

As it committed to "the long-range objective of encouraging and strengthening the private school movement," the Volker Fund also began fostering Christian primary and secondary schools, which were then quite rare. ${ }^{79}$

In short, there was broad support among libertarians for using the white fight against school integration to advance their cause. While Friedman and most of his neoliberal collaborators made their case for privatization in race-neutral language and may not personally have been driven by racial animus, they had no scruples about exploiting

\footnotetext{
${ }^{74}$ Milton and Rose D. Friedman, Two Lucky People, 338-340.

${ }^{75}$ Ivan R. Bierly to Kilpatrick, July 8, 1959, box 26, Series B, Kilpatrick Papers; Bierly to Kilpatrick, Oct. 2,1959 , ibid.

${ }^{76}$ Friedman to Nutter, May 4, 1960, box 31, Friedman Papers; Janet W. Miller to Leon Dure, Sept. 25, 1961, box 3, Dure Papers; Glickman, "Virginia Desegregation," 97-98.

${ }^{77}$ Kenneth S. Templeton to Leon Dure, July 7, 1960, box 3, Dure Papers; Anon., "Back to McGuffey," Time, May 19, 1961, 64.

${ }^{78}$ Leon Dure to Kilpatrick, April 22, 1961, box 1, series JKM, JJK. Alas for the scheme, Kirchanski wanted more guaranteed profit up front, so the collaboration fizzled. Kirchanski to Dure, April 13, 1961, box 3, Dure Papers.

${ }^{79}$ Janet W. Miller to Leon Dure, Sept. 25, 1961, box 3, Leon Dure Papers, University of Virginia Special Collections Library, Charlottesville, VA; Kenneth S. Templeton to Leon Dure, July 7, 1960, box 3, Dure Papers; Leon Dure to Kilpatrick, April 22, 1961, box 1, acc. JKM, Kilpatrick Papers. On billionaire backing of Christian schools since, see Anne Nelson, Shadow Network: Media, Money, and the Secret Hub of the Radical Right (New York: Bloomsbury, 2019); Katherine Stewart, The Power Worshippers: Inside the Dangerous Rise of Religious Nationalism (New York: Bloomsbury, 2020).
} 
white supremacy to move their otherwise unsaleable policy agenda.

\section{V}

Most people equate freedom with democracy and the right to dissent, organize, and have a say in self-government. But the fight over school desegregation in the South helps us appreciate that freedom had a very different meaning for libertarians and neoliberals, an understanding they shared with defenders of racial segregation. One stark fact illustrates neoliberalism's peculiar idea of liberty, not as freedom from domination but as freedom to dominate.

Not one of these private school backers ever complained that the set of massive resistance laws which sent subsidies to segregation academies also denied First Amendment rights to members of the NAACP. Along with the tax subsidies for private schools, Virginia passed seven statutes designed to stymie the NAACP's legal efforts and open the organization's membership to segregationist retaliation. The laws threatened NAACP lawyers who brought desegregation suits with disbarment and criminal prosecution; required all organizations working on racial matters to file their membership rolls with the state; and created two investigative committees to enforce the rules. "We can bust that organization wide open," gloated one advocate of the laws. He was right. The NAACP lost one of every three members in a single year thanks to what an American Jewish Congress study found to be the region's "most elaborate, systematic and sophisticated attempt to frustrate NAACP activity." ${ }^{" 80}$ But none of the voucher supporters objected.

Their silence underscores a larger truth: Milton Friedman and his allies provided aid and comfort to those who presided over a racial dictatorship in the Jim Crow South, an apartheid-like regime that stayed in power through state-sponsored repression, employer retaliation and private violence. The collaboration between neoliberals and segregationists involved opportunism on both parts, to be sure. But what made it work

\footnotetext{
${ }^{80}$ American Jewish Congress, Assault upon Freedom of Association: A Study of the Southern Attack on the National Association for the Advancement of Colored People (New York, 1957), 27-29. See also the Scull v. Virginia Ex Rel. Committee on Law Reform and Racial Activities, 359 U.S 344 (1959), particularly the opinion by Justice Hugo Black.
} 
was the overlap in their values and views of government. Each placed a premium on the liberty of those who had long profited from racial capitalism and sought to shield it from government action on the part of Americans committed to democratic values. At a moment when at least some whites in the South were prepared to accept a more equitable society, neoliberals lined up with the beneficiaries of the old order. Not surprisingly, the outcome was not freedom, but the entrenchment of structural racism. ${ }^{81}$

And the sad fact of the matter is that improving education was never the true reason for free-market fundamentalists' embrace of vouchers. Friedman offers the best illustration, not least because he was the most honest about the endgame, for which he continued to work until his death. As Friedman signaled in that first 1955 manifesto and argued for over a half century, school "choice" was a waystation on the route to radical privatization. Vouchers were a tactic, but never the end in themselves. The strategy was to stick parents with the full cost of their children's schooling and the labor of finding and arranging it. The advocates never made that aim clear to the parents they sought - and seek--to win to the school choice cause.

"In my ideal world, government would not be responsible for providing education any more than it is for providing food and clothing," Friedman repeated in 2004 what he had long maintained. "Private charity would be more than ample to assure that there were schools available for every child." ${ }^{82}$ He was as frank in addressing a meeting of the

\footnotetext{
${ }^{81}$ By the time the U.S. Supreme Court ruled the "freedom of choice" vouchers unconstitutional in 1968, the Commonwealth of Virginia alone had spent some twenty million state dollars underwriting white private schools. The public subsidies - enabled by Black voter suppression and malapportionment of the General Assembly to overrepresent more conservative rural white residents and underrepresent more moderate city and suburban whites - enabled southern state legislatures to build up private education, particularly in Black majority counties where the greatest white flight occurred. This drain of public monies to segregation academies further beggared the already ill-supported public school system in the states of the former Confederacy. Andrew B. Lewis, "Emergency Mothers: Basement Schools and the Preservation of Public Education in Charlottesville," The Moderate's Dilemma: Massive Resistance to School Desegregation in Virginia, ed. Matthew D. Lassiter and Andrew B. Lewis (Charlottesville: University Press of Virginia, 1998), n. 73, 217-218; J. Douglas Smith, On Democracy's Doorstep: The Inside Story of How the Supreme Court Brought "One Person, One Vote" to the United States (New York: Hill \& Wang, 2014), 19.

${ }^{82}$ Milton Friedman, Nov. 11, 2004, box 211, Milton Friedman Papers, Hoover Institution Archives, Stanford University, Palo Alto, CA. Such candid statements that "vouchers are an expedient to get from where we are to where we want to go" litter Friedman's correspondence with allies who sought to use limited, urban voucher plans as the proverbial camel's nose in the public tent. They disagreed over tactics, not the end goal. To choose just one exchange, with the president of the Liberty Fund: "Neither choice nor vouchers is our real objective. Our real objective is privatization of the school system. That is what is absolutely essential.... a socialist system will teach socialism; we cannot expect it to do anything else. I
} 
ALEC four months before his death in 2006. Said Friedman: "the ideal way [to give parents control of their children's education] would be to abolish the public school system and eliminate all the taxes that pay for it." ${ }^{83}$ In the real world, this would be engineered inequality so staggering that it would make today's inequities look modest by comparison.

That is what today's libertarian billionaire backers of vouchers, with Charles G. Koch in the lead, are keeping from the unsuspecting parents on whom the cause relies for electoral success, now Black and Latino as well as white. ${ }^{84}$ Vouchers, like freedom, are a horse to ride somewhere. The destination would shock most people, but soon it could be too late to reverse course.

view vouchers as a step in the direction of eliminating government subsidization of schooling altogether, except perhaps as a poor relief measure." Friedman to W.W. Hill, box 212, Friedman Papers.

${ }^{83}$ Friedman speaking at July 21, 2006 ALEC meeting in San Francisco in footage shown in the Moyers and Company 2013 documentary, The United States of ALEC: A Follow-Up. I thank Lisa Graves, Executive Director of True North Research, whose research for ALEC Exposed guided the documentary, for alerting me to this clip, which appears at minute 28:

https://billmoyers.com/episode/united-states-of-alec-a-follow-up/

${ }^{84}$ On the new Koch push announced in 2019, see Andrew Ujifusa, "Koch Network Announced New Education Lobbying Group, Walton Funding Pact," EducationWeek, June 29, 2019:

https://www.edweek.org/education/koch-network-announces-new-education-lobbying-group-waltonfunding-pact/2019/06 . For the successful Save Our Schools campaign in Arizona, reminiscent of the antivoucher organizing in Virginia, see Steven Greenhouse, "Billionaires v. Teachers: The Koch Brothers' Plan to Starve Public Education," Sept. 7, 2018:

https://www.theguardian.com/us-news/2018/sep/07/arizona-fight-koch-brothers-school-vouchers. 


\section{References}

American Jewish Congress. Assault upon Freedom of Association: A Study of the Southern Attack on the National Association for the Advancement of Colored People. New York: American Jewish Congress, 1957.

Andrews, T. Coleman. Papers, Division of Special Collections. University of Oregon Libraries.

Bartley, Numan V. The Rise of Massive Resistance: Race and Politics during the 1950s. Baton Rouge: Louisiana State University Press, 1969.

Blackford, Staige D. "Free Choice and Tuition Grants in Five Southern States," New South, April 1964.

Blum, Rev. Virgil C., S.J. Papers. Archives. Raynor Memorial Library. Marquette University. Milwaukee, WI.

Burgin, Angus. The Great Persuasion: Reinventing Free Markets since the Depression. Cambridge: Harvard University Press, 2012.

Cato Institute. Isabel Patterson: http://www.libertarianism.org/publications/essays/isabelpaterson.

Center for Media and Democracy, ALEC Exposed:

https://www.alecexposed.org/wiki/Privatizing_Public_Education, Higher_Ed Policy, an d Teachers

Chambers, Lenoir. Editorial: "To a Champion of the Tuition Grants," Norfolk VirginianPilot, July 30, 1960.

Cockett, Richard Thinking the Unthinkable: Think-Tanks and the Economic CounterRevolution, 1931-1983. London: HarperCollins, 1995.

Daugherity, Brian J. Keep on Keeping on: The NAACP and the Implementation of Brown v. Board of Education in Virginia. Charlottesville: University of Virginia Press, 2016.

Diane Ravitch's Blog: https://dianeravitch.net/.

Dillard, Hardy Cross. "Freedom of Choice and Democratic Values." Virginia Quarterly Review 38 (Summer 1962), 410-35.

Doherty, Brian. Radicals for Capitalism: A Freewheeling History of the Modern Libertarian Movement. Public Affairs, 2007. 
Dure, Leon. Papers. Special Collections Library. University of Virginia Charlottesville, VA.

Ebenstein, Lanny. Milton Friedman: A Biography. New York: Palgrave Macmillan, 2007.

EdChoice:

https://www .edchoice.org/who-we-are/our-founders/the-friedmans-on-school-

choice/article/the-role-of-government-in-education/

Freeman, Roger A. Federal Aid to Education - Boon or Bane? Washington, D.C.: American Enterprise Association, 1955.

---------. Papers. Hoover Institution Archives. Stanford University, Palo Alto, CA.

Friedman, Milton Papers. Hoover Institution Archives. Stanford University, Palo Alto, CA.

--------. “The Prospects for Neoliberalism.” Farmand, Feb. 17, 1951.

--------. "The Role of Government in Education." Economics and the Public Interest. Ed. Robert A. Solo. New Brunswick, N.J.: Rutgers University Press, 1955.

Friedman, Milton with the assistance of Rose D. Friedman, Capitalism and Freedom, 40 ${ }^{\text {th }}$ Anniversary Edition. 1962; reprint, Chicago: University of Chicago Press, 2002.

Friedman, Milton and Rose D. Friedman, Two Lucky People: Memoirs. Chicago: University of Chicago Press, 1998.

Glickman, Andrew Ziet. "Virginia Desegregation and the Freedom of Choice Plan: The Role of Leon Dure and the Freedom of Association." M.A. Thesis, University of Virginia, 1991.

Gravatt, John Segar. Papers. Special Collections Library. University of Virginia, Charlottesville, VA.

Greenpeace. Foundation for Economic Education (FEE): Koch Industries Climate Denial Front Group: https://www .greenpeace.org/usa/ending-the-climate-crisis/climatedeniers/front-groups/foundation-for-economic-education-fee/

Greenblatt, Alan. "School Choice Advances in the States: Advocates Describe 'Breakthrough Year,' Education Next, Summer 2021:

https://www.educationnext.org/school-choice-advances-in-states-advocates-describebreakthrough-year/?utm source=pocket mylist. 
Greenhouse, Steven, "Billionaires v. Teachers: The Koch Brothers' Plan to Starve Public Education," Sept. 7, 2018:

https://www .theguardian.com/us-news/2018/sep/07/arizona-fight-koch-brothers-schoolvouchers.

Hayek, Friedrich A. Papers. Hoover Institution Archives. Stanford University. Palo Alto, CA.

The Road to Serfdom 1944; reprint, Chicago: University of Chicago, 1994.

Hershman, James H. Jr. "The Emergence of the 'Virginia Plan' of Private Segregation Academies.” July 30, 2012. Unpublished paper in author's possession.

Leon S. Dure (1907-1993), Encyclopedia of Virginia:

https://encyclopediavirginia.org/entries/dure-leon-s-1907-1993.

--------. “The Origins of Massive Resistance," Encyclopedia Virginia:

https://encyclopediavirginia.org/entries/massive-resistance/

---------. "A Rumbling in the Museum: The Opponents of Virginia's Massive

Resistance." Ph.D. Dissertation, University of Virginia, 1978.

."The Wayward Liberal” and Virginia's Massive Resistance: Donald Richberg, Libertarian Economics, and Militant Segregation." Unpublished article in author's possession.

Hilts, Philip J. "The Saga of James J. Kilpatrick." Potomac magazine of the Washington Post, Sept. 16, 1973.

Horn, Rob van and Philip Mirowski. "The Rise of the Chicago School of Economics and the Birth of Neoliberalism," The Road from Mont Pelerin: The Making of the Neoliberal Thought Collective, ed. Philip Mirowski and Dieter Plehwe. Cambridge: Harvard University Press, 2009.

Hustwit, William P. James J. Kilpatrick: Salesman for Segregation. Chapel Hill: University of North Carolina Press, 2013.

In the Public Interest. Education reporting:

https://www.inthepublicinterest.org/category/sectors/education/

“Integration Foes Boo Fairfax P-TA, Take over Workshop Meeting Hall." Washington Post and Times Herald, May 1, 1955, A1.

Jones, Sam M. "Tidewater State Leads South in Seeking Way out of the Desegregation Crisis." National Review, Dec. 28, 1955, 23. 
Kilpatrick, James Jackson. Papers. Special Collections Library. University of Virginia Charlottesville, VA.

\section{---------. The Sovereign States: Notes of a Citizen of Virginia. Chicago: Henry Regnery} Company, 1957.

Koch Docs. Institute for Humane Studies:

https://kochdocs.org/?s=\%22institute+for+humane+studies $\% 22$

Kruse, Kevin M. White Flight: Atlanta and the Making of Modern Conservatism. Princeton: Princeton University Press, 2005.

Lewis, Andrew B. "Emergency Mothers: Basement Schools and the Preservation of Public Education in Charlottesville." The Moderate's Dilemma: Massive Resistance to School Desegregation in Virginia. Matthew D. Lassiter and Andrew B. Lewis, eds. Charlottesville: University Press of Virginia, 1998.

MacLean, Nancy. Democracy in Chains: The Deep History of the Radical Right's Stealth Plan for America. New York: Viking Press, 2017.

Mayer, Jane Dark Money: The Hidden History of the Billionaires Behind the Rise of the Radical Right. New York: Doubleday, 2016.

McCrary, Samuel E. "Challenge in Virginia." Washington Post and Times Herald, Dec. $12,1955,18$.

McGreevy, John T. Parish Boundaries: The Catholic Encounter with Race in the Twentieth-Century Urban North. C Chicago: University of Chicago Press, 1996.

McVicar, Michael. "Aggressive Philanthropy: Progressivism, Conservatism, and the William Volker Charities Fund.” Missouri Historical Review 105, n. 4 (2011).

Mirowski, Philip and Dieter Plehwe, eds. The Road from Mont Pèlerin: The Making of the Neoliberal Thought Collective. Cambridge: Harvard University Press, 2009.

Morley, Felix. Freedom and Federalism. Chicago: Henry Regnery Company, 1959.

Muse, Benjamin “'Defenders' Trample True Traditions," Washington Post and Times Herald, May 8, 1955, E2.

Moyers and Company. The United States of ALEC: A Follow-Up. Documentary, 2013: https://billmoyers.com/episode/united-states-of-alec-a-follow-up/

Moynihan, Daniel P. Papers. Manuscript Division. Library of Congress. Washington, DC. 
Nelson, Anne. Shadow Network: Media, Money, and the Secret Hub of the Radical Right. New York: Bloomsbury, 2019.

Patterson, Isabel. “The Southern Breakthrough.” National Review, Dec. 21, 1955, 9-12.

Phillips-Fein, Kim. Invisible Hands: The Businessmen's Crusade against the New Deal. New York: W. W. Norton, 2009.

Poole, Robert W. Jr, "Reason and Ecology." Outside, Looking in: Critiques of American Policies and Institutions, Left and Right. New York: Harper \& Row, 1972.

Rasche, Pamela Jane "Leon Dure and the 'Freedom of Association.'" Unpublished thesis, University of Virginia, 1977.

Regnery, Henry. Papers. Hoover Institution Archives. Stanford University, Palo Alto, CA.

Richmond News Leader, various dates.

Roberts, Gene and Hank Klibanoff. The Race Beat: The Press, the Civil Rights Struggle, and the Awakening of a Nation. New York: Random House, 2006.

Schulman, Daniel. Sons of Wichita: How the Koch Brothers Became America's Most Powerful and Private Dynasty. New York: Grand Central Publishing, 2015.

Scull v. Virginia Ex Rel. Committee on Law Reform and Racial Activities, 359 U.S 344 (1959).

Smith, J. Douglass. Managing White Supremacy: Race, Politics and Citizenship in Jim Crow Virginia. Chapel Hill: University of North Carolina Press, 2002.

-------. On Democracy's Doorstep: The Inside Story of How the Supreme Court Brought "One Person, One Vote" to the United States. New York: Hill \& Wang, 2014.

Stewart, Katherine. The Power Worshippers: Inside the Dangerous Rise of Religious Nationalism. New York: Bloomsbury, 2020.

Taylor, Stephen P. and Natalie B. Taylor, "Aid to Private Schools," Washington Post and Times Herald, Dec. 9, 1955, 18.

Ujifusa, Andrew. "Koch Network Announced New Education Lobbying Group, Walton Funding Pact." EducationWeek, June 29, 2019: https://www.edweek.org/education/kochnetwork-announces-new-education-lobbying-group-walton-funding-pact/2019/06 .

UnKoch My Campus. “Increased Spending, Increased Influence.” May 2021: http://www.unkochmycampus.org/funding-report. 
Suitts, Steve. Overturning Brown: The Segregationist Legacy of the Modern School Choice Movement. Montgomery, AL: New South Books, 2020.

---------. "Segregationists, Libertarians, and the Modern School Choice Movement," Southern Spaces, June 4, 2019.

Ward, Jason Morgan. Defending White Democracy: The Making of a Segregationist Movement and the Remaking of Racial Politics, 1936-1965. Chapel Hill: University of North Carolina Press; 2011.

Williams, Harley M. “The Gray Proposal: Pro and Con,” Dec. 18, 1955.

---------. "Virginia School Proposal," Washington Post and Times Herald, Oct. 16, 1955, E4.

Wright, Gavin. Sharing the Prize: The Economics of the Civil Rights Revolution in the American South. Cambridge: Harvard University Press, 2013. 